\title{
混合すべり条件下におけるレール摩耗形状予測モデルの構築
}

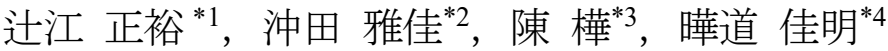

\section{Development of a model for predicting worn profile of rail under the mixed slip conditions}

\author{
Masahiro TSUJIE ${ }^{* 1}$, Masayoshi OKITA ${ }^{* 2}$, Hua CHEN $^{* 3}$ and Yoshiaki TERUMICHI ${ }^{* 4}$ \\ ${ }^{* 1}$ Railway Dynamics Division, Railway Technical Research Institute \\ 2-8-38 Hikari-cho, Kokubunji-shi, Tokyo 185-8540, Japan \\ ${ }^{* 2}$ Department of Science and Technology, Graduate School of Sophia University \\ 7-1 Kioi-cho, Chiyoda-ku, Tokyo 102-8554, Japan \\ ${ }^{* 3}$ Railway Dynamics Division, Railway Technical Research Institute \\ 2-8-38 Hikari-cho, Kokubunji-shi, Tokyo 185-8540, Japan \\ ${ }^{*}$ Department of Science and Technology, Sophia University \\ 7-1 Kioi-cho, Chiyoda-ku, Tokyo 102-8554, Japan
}

Received: 1 March 2020; Revised: 1 June 2020; Accepted: 29 June 2020

\begin{abstract}
Rail wear does not develop in a short term, but it is closely related to crack initiation. Furthermore, there is a possibility that the worn profile of rail influences the curving performance or the running stability. However, worn profiles of rail changes complexity in each section (e.g. straight section, transition curve section, circular curve section) because the condition of wheel/rail contact changes gradually, according to the running condition of vehicle and track geometry conditions. Predicting the worn profiles of rail should be considered based on the results of the vehicle dynamics analysis. Therefore, it is very beneficial to predict the worn profiles of rail based on the analysis by using multibody dynamics. The purpose of this study is to develop the prediction model for worn profile of rail under the various angle of attack by using multibody dynamics. Especially, we focused on the wear development due to longitudinal slip and lateral slip. In the beginning of this study, the wear experiment was conducted by using the wheel/rail rolling contact equipment under the mixed slip conditions. Secondary, the prediction model with Simpack was developed. Then, wear predicting analysis was conducted in the same contact conditions as the experiments. Finally, we evaluated the results of analysis to validate the developed model under the various mixed slip conditions. As a result of the experiment and the analysis, it was revealed that the wear development under the mixed slip conditions can be evaluated by the contribution ratio of longitudinal slip and lateral slip.
\end{abstract}

Keywords : Wear development, Wear prediction, Wheel/rail, Archard, Multibody dynamics, Rolling contact, Slip

\section{1. 緒言}

レールは鉄道固有の要素であり, 車両の支持や案内, 駆動力や制動力の伝達といった重要な役割を担っている. 営業線に敷設されたレールにおいては，通過する車輪との転がり接触により，摩耗や損傷といった事例の発生が 散見される. シェリングに代表するようなレール損傷事例は，大きく進展するとレール折損を引き起こす恐れが あることから, き裂の進展状況を適切に管理するとともに, その進展状況を精度よく予測することが重要である. これまでレールにおけるき裂進展予測については，室内試験や数值解析により検討した例が報告されている，一 方，レールにおける摩耗進展は，き裂進展に比べると急激に進展することはないものの，シェリングやきしみ割 れといったき裂の発生と密接な関係がある(栗原，1981) (金他, 2006) (Zhou et al., 2014) (Rene and Marcel, 2014)。ま た摩耗により，レールの車輪と接触する面の断面形状が変化(瀧川他，2002)すると，通過する車輪との接触状態

\footnotetext{
No.20-00056 [DOI:10.1299/transjsme.20-00056], J-STAGE Advance Publication date : 8 July, 2020

*1 正員，鉄道総合技術研究所 鉄道力学研究部（干185-8540 東京都国分寺市光町 2-8-38)

*2 学生員, 上智大学大学院 理工学研究科（广102-8554 東京都千代田区紀尾井町 7-1)

*3 鉄道総合技術研究所 鉄道力学研究部

*4 正員, フェロー，上智大学 理工学部

E-mail of corresponding author: tsujie.masahiro.13@rtri.or.jp
} 
が変化し，車両の走行安定性や乗心地に影響寸る可能性も考えられる．したがってレールにおいては，き裂の発 生や進展を予測することに加えて，摩耗進展を精度よく予測することも重要である.

レールにおける摩耗進展状況は，車輪との接触状態に依存し，それらは直線区間や曲線区間といったレール敷 設状況や車両の走行条件によって, 複雑に変化する. そこで, レールの摩耗進展予測を精度良く行うためには, 車両運動に基づいた車輪／レール接触状態から検討しなければならない. これらの観点から, 筆者らは先行研究 にて，マルチボディダイナミクスツールである Simpack(ver. 9.8)（以下，「Simpack」とする）を援用したレール摩 耗形状予測モデルを構築し(辻江他, 2013), 大型転動疲労試験機による室内摩耗試験ならびに摩耗進展解析によ り，モデルの妥当性を検証した(辻江他，2017)。一方，これまでの摩耗進展予測(Telliskivi, 2004) (金他, 2009) (土 井他，2011)においては，接触面内における縦すべり（転動方向と同じ方向のすべり）と横す心゙り（転動方向に対 して直角方向のすべり）の影響は同等であるとみなして扱われてきた．しかし，実際の曲線区間における車輪／ レール接触部にみられるような, アタック角を生じた接触条件下においては, 縦すべりと横すべりにおける摩耗 進展速度の差にも着目しなければならない. そこで, 筆者らは先行研究(辻江他, 2018)において, より高精度な 摩耗進展予測を行うために, 縦すべりと横すべりが摩耗進展に及ぼす影響について検討した。 そして, 縦すべり と横すべりにより摩耗進展速度の差を明らかにするとともに, 進展速度の差を考慮した摩耗進展予測モデルを構 築した. しかし実際の車輪/レール接触においては, 縦すべりと横すべりは独立して発生するものではなく, 接 触面内において同時に発生する.つまり, 縦すべりと横すべりが同時に作用したすべり条件 (以下,「混合すべり」 とする）による摩耗進展については, 新たに検討する必要がある. 一方で, 車輪/レール接触部において発生す る縦すべりと横すべりの值は, アタック角や曲線半径をはじめ, 車輪/レール接触位置など, さまざまな要因に よって複雑に変化する. 混合すべりによる摩耗進展を簡易に, かつ精度よく予測する手法を構築することができ れば, 縦すべりと横すべりが複雑に変化する車輪/レール接触における摩耗進展に対して, さまざまな条件での 室内摩耗試験による検討をせずに，その進展を予測することが期待できる.

そこで本研究では, 大型転動疲労試験装置を用いた室内摩耗試験を実施し, 混合すべりによる摩耗進展につい て検討するとともに，混合すべりによる摩耗進展を評価する予測式を提案した，さらに，室内摩耗試験と同じ条 件での摩耗進展解析を実施し, 摩耗進展の予測式について妥当性を評価した.

\section{2. アタック角とすべり率}

本章では，列車が曲線区間を通過する際の車輪/レール接触部における，アタック角とすべり率の関係につい て記述する。

列車が曲線区間を通過する際の車輪/レール接触部を模擬した，転動疲労試験装置における試験輪同士の接触 状態を図 1 に示す.

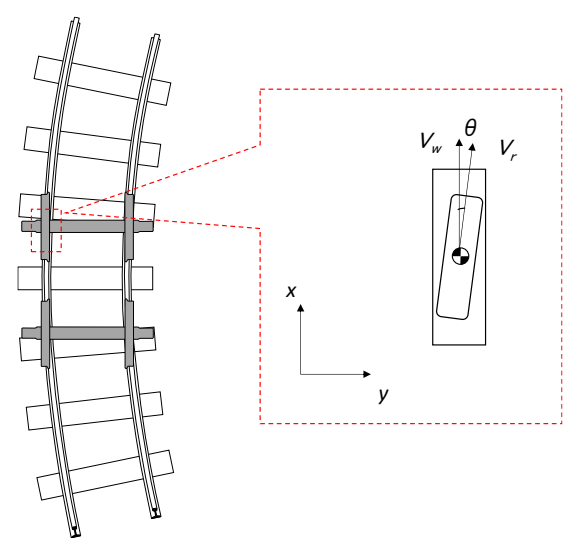

Fig. 1 The illustration of the contact condition between the wheel disc and the rail disc simulated the wheel/rail contact in curved section. In this figure, $V_{w}$ is the rotation speed of wheel disc and $V_{r}$ is the rotation speed of rail disc. Furthermore, $\theta$ indicates the angle of attack between wheel/rail. 
ここで， $\theta$ はアタック角， $V_{w}$ は車輪試験輪の転動速度， $V_{r}$ はレール試験輪の転動速度である。この場合，試験 輪の接触部に発生する縦すべり率ならびに横すべり率は，以下の式で与えられる．ただし， $\delta_{x}$ は縦すべり率， $\delta_{y}$ は横すべり率である.

$$
\begin{aligned}
& \text { （縦すべり率） } \\
& \qquad \delta_{x}=\frac{2\left(V_{w}-V_{r} \cos \theta\right)}{V_{w}+V_{r}}
\end{aligned}
$$

(横すべり率)

$$
\delta_{y}=\frac{2 V_{r} \sin \theta}{V_{w}+V_{r}}
$$

\section{3. 室内摩耗試験}

本章では, 混合すべり条件下における摩耗進展の評価, ならびに摩耗進展の評価指標の一つである摩耗係数を 同定するため，大型転動疲労試験装置を用いた室内摩耗試験を実施した．以下にその詳細を記述する.

\section{$3 \cdot 1$ 試験装置の概要}

室内摩耗試験は，鉄道総研所有の車輪・レール高速接触疲労試験装置(名村，石田，2011)を用いて行った．本 試験装置の概略図を図 2 に示寸.

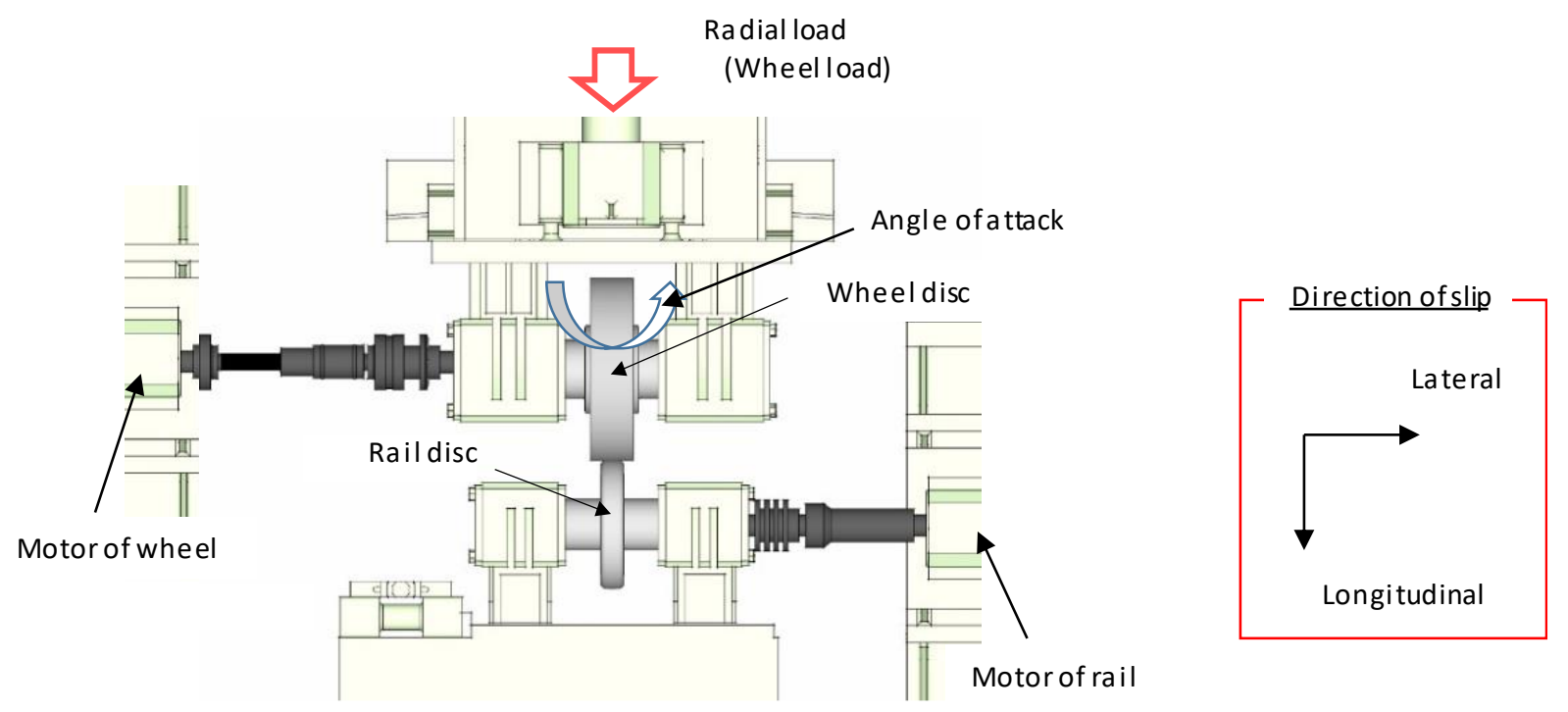

Fig. 2 Equipment of wear experiment. Mainly, this equipment consists of two discs (that is wheel and rail) and two motors which are connected each discs. As is a feature of this equipment, both discs are rotated independently by separate motors. Therefore, an arbitrary slip or torque can be generated on the contact patch between wheel and rail discs. Moreover, the angle of attack is applied by moving the axis of the wheel disc.

本試験装置では，車輪材試験輪（以下，「車輪」とする）ならびにレール材試験輪（以下，「レール輪」とする） を組み合わせ，任意に指定したすべり率や接触荷重 (輪重ならびに横圧), アタック角の条件下において転動試験 を行うことができる. 本試験装置に組み込む試験輪は, それぞれ車輪鋼ならびにレール鋼から切り出したもので 
ある．本試験装置は，両方の試験輪をそれぞれ独立したモータで転動させることから，試験輪の接触面において 発生するすべりやトルクを制御することがでさる．さらに，車輪の回転軸を傾斜させることにより，アタック角 を付与することができる，本研究では，縦すべりについてはそれぞれの試験輪の転動速度を制御することで，ま た横すべりについてはアタック角を車輪に付与することで，試験輪の接触面に任意の縦すべりと横すべりを発生 させた。

\section{$3 \cdot 2$ 試験条件}

室内摩耗試験は，表 1 に示すレール輪ならびに車輪を組み合わせて実施した．特に車輪については，試験輪の 接触面にスピンを発生させない(日本トライボロジー学会，2007)よう，転動面の断面形状は傾斜のない直線（す なわち $\mathrm{R}=\infty)$ とした。

Table 1 Conditions of the experimental discs.

\begin{tabular}{c|c|c|c}
\hline Disc & Diameter & Profile & Hardness \\
\hline \hline Wheel & $\phi 500 \mathrm{~mm}$ & $\begin{array}{l}\text { Cylinder } \\
(\mathrm{R}=\infty)\end{array}$ & $330 \mathrm{HV}$ \\
\hline Rail & $\phi 350 \mathrm{~mm}$ & $\begin{array}{l}\text { JIS 60kg Rail } \\
(\mathrm{R}=600 \mathrm{~mm})\end{array}$ & $275 \mathrm{HV}$ \\
\hline
\end{tabular}

本研究で行った室内摩耗試験の試験条件を表 2 に示す. Case1 では同じすべり率の縦すべりと横すべりが発生 する条件とした．接触面に付与するすべり率については，先行研究(辻江，2018)で実施した試験条件に基づき， 0.35\%のすべり率の縦すべりと横すべりが発生する条件とした. 一方, Case2 では縦すべりと横すべりのすべり率 を変更させた条件として，縦すべり率については Case1 と同じ $0.35 \%$ と，横すべりについては Case1の半分の すべり率が発生する条件とした。そこで，車輪に付与するアタック角は，式(2)より $0.1^{\circ}$ とした。また，いずれ の試験条件においても，試験輪に載荷する垂直荷重については，先行研究(辻江，2017) (辻江，2018)と同様，試 験輪の接触部における最大接触面圧が $800 \mathrm{MPa}$ 程度 (在来線の一般的な車両における車輪／レール接触面圧と同 程度）となるよう, 試験輪に $10 \mathrm{kN}$ を載荷した。

Table 2 Conditions of the experiment.

\begin{tabular}{c|c|c|c|c|c|c}
\hline \multirow{2}{*}{ Case } & \multirow{2}{*}{$\begin{array}{c}\text { The Angle of Attack } \\
{[\mathrm{deg}]}\end{array}$} & \multicolumn{2}{|c|}{ Rolling Speed $[\mathrm{km} / \mathrm{h}]$} & \multicolumn{2}{|c|}{ Slip Ratio [\%] } & \multirow{2}{*}{$\begin{array}{c}\text { Normal Contact Force } \\
{[\mathrm{kN}]}\end{array}$} \\
\cline { 3 - 6 } & 0.2 & Wheel & Rail & Longitudinal & Lateral & \multirow{2}{*}{10} \\
\hline \hline 1 & 0.1 & 60.21 & 60.00 & 0.35 & 0.35 & 0.17 \\
\hline
\end{tabular}

各試番とも，レール輪の転動回数が 100 万回になるまで試験輪を転動させた.また，転動回数が 25 万回ごとに 試験輪の転動を中断し, Greenwood 社製の Miniprof を用いて試験輪の断面形状を測定した.

\section{$3 \cdot 3$ 試験結果}

前節で紹介した摩耗試験の結果について以下に記載する.

(1) 摩耗断面形状

レール輪が 25 万回転動するごとに測定した試験輪の断面形状と, 転動前の初期形状を重ね合わせた. なお試験 輪の断面形状測定は，試験輪にあらかじめ定めた測定箇所 2 点（2 点は転動面の 180 離れた箇所）において行っ た. そのうち 1 点について, Case1 と Case2 の初期形状ならびに各測定時における測定結果を重ねたものを, 図 3 に示す．なお，いずれも摩耗による試験輪の形状変化をより明確に示すため，縦軸については拡大して表示して いる. 


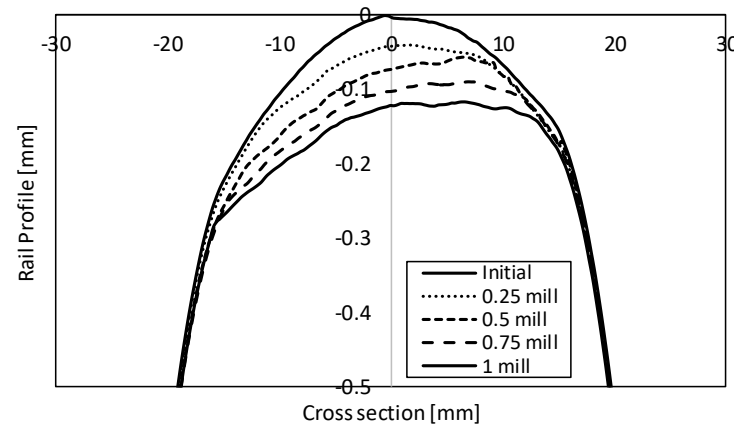

(a) Case 1

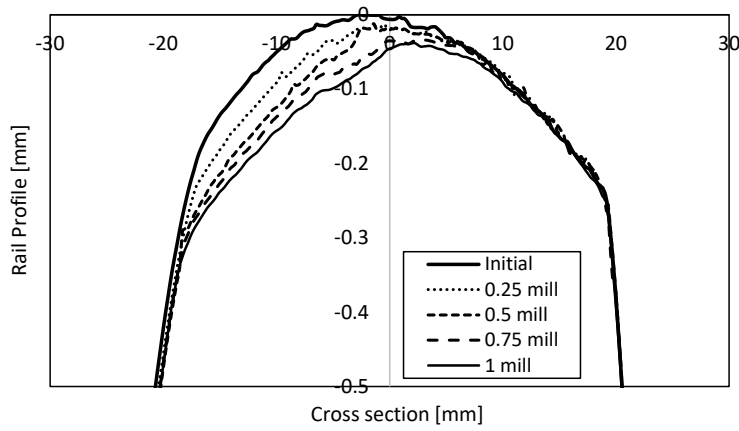

(b) Case 2

Fig. 3 The progress of worn profiles of rail discs at every 0.25 million rotation. (a) Profiles of rail disc for Case 1. (b) Profiles of rail disc for Case 2 .

図 3 より，いずれの条件においても転動回数が増加するにつれて摩耗深さや摩耗帯域が増加し，摩耗進展して いることが確認できる．なお図 3(b)に示す Case2 における摩耗進展状況は，図 3(a)に示す Case1 における摩耗進 展状況に比べて，摩耗帯域が狭くなっていることが確認できる。これは, Case2 で用いた車輪/レール輪におけ る試験開始前の初期形状において，設計形状から誤差が生じていた可能性が考えられる，そして結果として，試 験輪の接触状態に偏りが生じたことが原因であると考えられる.

(2) 摩耗分布

（1）で行った新品形状と摩耗断面形状の重ね合わせた結果より，25 万回転動ごとのレール輪における摩耗量の 分布を算出した。それらの結果を図 4 に示寸.

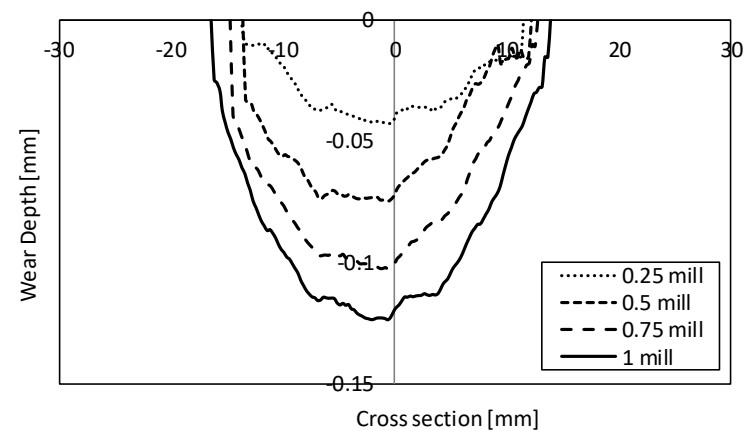

(a) Case 1

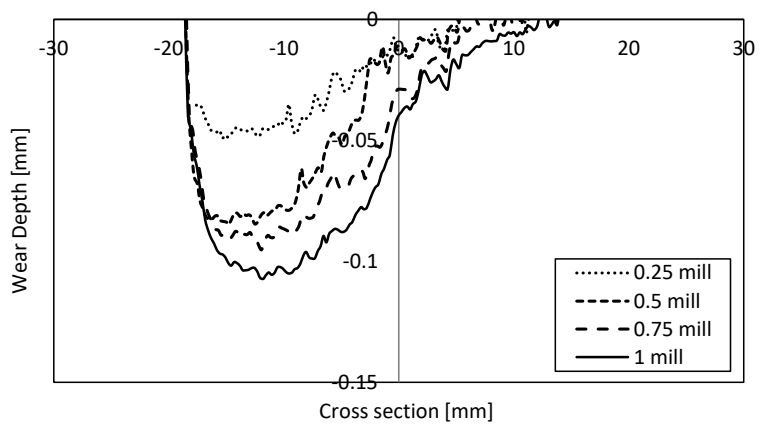

(b) Case2

Fig. 4 The results of wear amount distribution of rail disc. Wear amount distributions are calculated from the measurement results of initiation profiles and worn profiles. (a) Wear amount distribution of rail disc for Case 1 at every 0.25 million rotation. (b) Wear amount distribution of rail disc for Case 2 at every 0.25 million rotation.

図 4 に示すように, いずれの条件においても転動回数が増加するにつれて, 摩耗深さや摩耗帯域が増加してい ることが確認できる．また全体的な傾向として，アタック角の大きい Case1 における摩耗進展のほうが，Case2 における摩耗進展よりも速いことが確認できる. これは, Case1 におけるアタック角が大きいため, Case2 に比べ て大きな横すべりが発生したことが影響していると考えられる. また図 3 と同様, Case2 においては摩耗領域が 偏っていることが確認できる. 


\section{(3) 摩耗量}

前項で行った，新品断面形状と摩耗断面形状の重㸚わせによる摩耗分布より，図 5 の算出方法に基づく式(3) を適用して, 25 万回転動ごとのレール輪の摩耗量 $W$ を求めた. それらの結果を図 6 に示寸. なお式(3)において, фはレール輪径である.

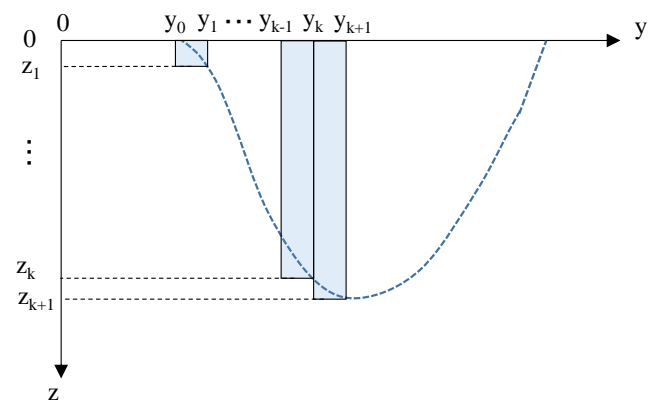

Fig. 5 The outline of wear amount. The amount of wear volume is calculated by integrating the wear depth.

$$
W=\pi \phi \sum_{k=1}^{n} z_{k} \times\left(y_{k}-y_{k-1}\right)
$$

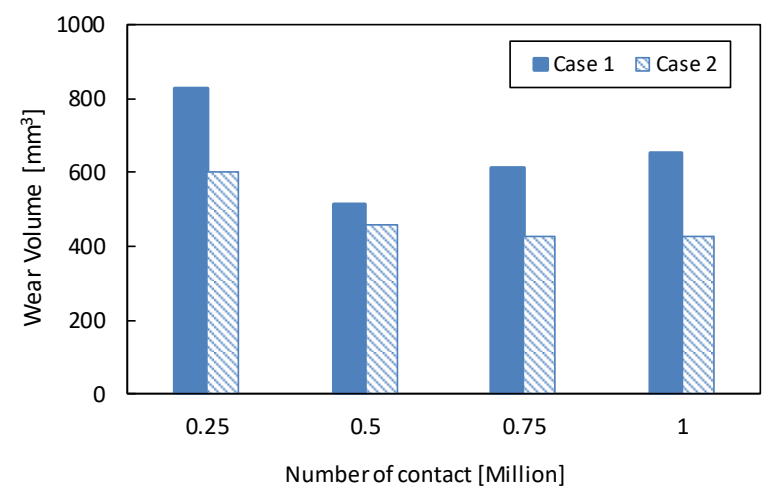

Fig. 6 Results of the wear volume at every 0.25 million rotations. The horizontal line represents the number of rolling contact and the vertical line represents the wear volume.

このように，Case1 ならびに Case2 ともに，試験開始から 25 万回転動までとそれ以降において，摩耗量が異な っていることが確認できる．この傾向は，試験開始直後における初期摩耗が影響していると考えられる．また全 体的に, アタック角の大きいCase1 のほうが, Case2 に比べて摩耗量が多い結果となっていることも確認できる.

\section{4. 摩耗係数の推定}

車輪/レール接触における摩耗は，主に凝着摩耗である(金他，2009). 凝着摩耗に対寸る予測式として，これ までにいくつかの摩耗則(Archard, 1953) (Kalousek and Bethune, 1978) (Elkins and Eickhoff, 1979) (Ward et al., 2003)が 提案されている，そのうちの1つである Archard 摩耗則については，式(4)で定義される. 


$$
D=\frac{k \cdot P \cdot \delta}{H}
$$

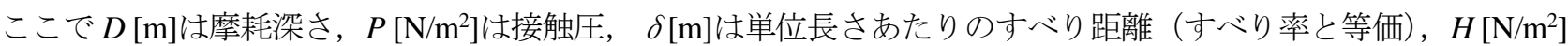
は接触する二つの物体の硬さのうち柔らかいほうの硬さである。 また $k$ は摩耗係数であり, 摩耗進展を評価する 係数として定義され，材料固有の值として与えられる．なお図 1 に示すように，車輪がアタック角を有した状態 でレールと接触する場合, 接触面内において縦すべりと横すべりが発生する. Archard 摩耗則では, 縦すべり率 $\delta_{x}$ ならびに横すべり率 $\delta_{y}$ より，以下の式(5)で与えられる総すべり率 $\delta$ とて摩耗量を算出している.

$$
\delta=\sqrt{\delta_{x}^{2}+\delta_{y}^{2}}
$$

式(4)で示寸摩耗係数については, 先行研究(Arizon et al., 2007) (下川他, 2010) (Ignesti et al., 2012) (Bevan et al., 2013)より摩耗形態に応じて摩耗係数を変化させるほか, 先行研究(辻江他，2018)では縦すべりと横すべりによる 摩耗進展の差についても，摩耗係数を置き換えることで適用できることを示している，そこで本研究では，混合 すべり条件下における摩耗進展についても摩耗係数を新たに定義することで，その進展を評価することが可能か 検討した.

はじめに，前章で算出した摩耗量をもとに式(3)に示す Archard 摩耗則を適用し，本研究で行った室内摩耗試験 結果より，レール輪の摩擦係数を同定した．その結果を図 7 に示す。また先行研究(辻江他，2018)で実施した， すべり率 0.35\%の縦すべりのみ，ならびに横すべりのみが作用した条件における室内摩耗試験結果から同定した 摩耗係数についても合わせて示す．なお先行研究(辻江他，2018)において，同じす心゙り率でもすべりの方向によ って接触面に作用寸る応力の差が影響し, 摩耗量に差が生じる結果となっている. また, その差は摩耗係数にも 反映され，横すべり率による摩耗係数は縦すべりに比べて約 1.7 倍高い值となっている.

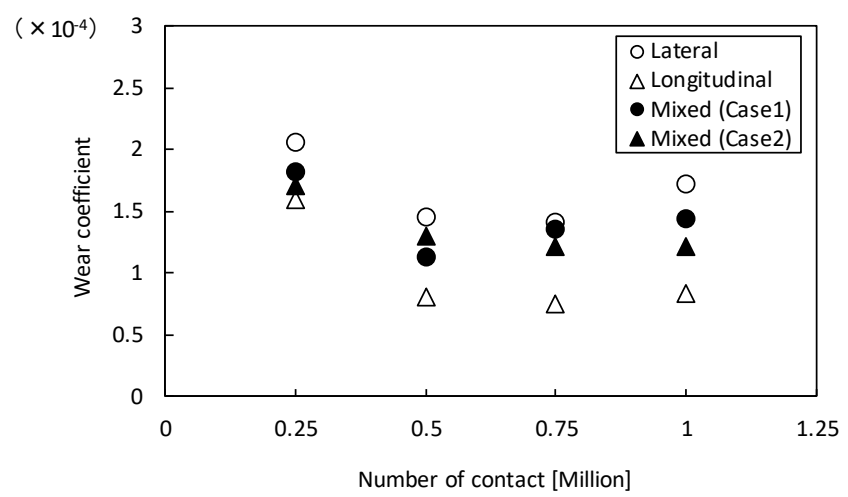

Fig. 7 The results of the wear coefficient of rail disc at every 0.25 million rotations. The wear coefficient under the lateral slip condition or the longitudinal slip condition were calculated in the previous research. On the other hand, the wear coefficient under the mixed slip conditions are calculated by the results of wear experiment in this study.

図 7 に示寸ように, アタック角が $0.2^{\circ}$ の混合すべり条件下における Case 1 での摩耗係数は, アタック角が $0.1^{\circ}$ の混合すべり条件下における Case2 での摩耗係数に比べて, 1.1 倍程度高い值となった. またいずれの条件とも, 同定された摩耗係数の值は，先行研究で実施した縦すべりならびに横すべりのみの摩耗進展から同定された摩耗 係数の範囲に収まっていることが確認できる.

先行研究(辻江他, 2018)より, すべり率が $0.35 \%$ の場合, 横すべりによる摩耗進展は縦すべりによる摩耗進展よ り約 1.7 倍促進することが明らかとなっている. そして，この摩耗進展速度の差は，摩耗係数に反映することで その進展状況を予測することができる．図７に示すように，先行研究において室内摩耗試験結果から同定した摩 
耗係数についても, 横すべりの摩耗係数は縦すべりの摩耗係数の約 1.7 倍高い值となっている. 一方, 本研究で 行った混合す心゙り条件下における摩耗進展は, 縦すべりと横す心゙りが同時に作用しているため, 同じす心゙り率に おける摩耗進展速度という観点からは，横すべりのみによる摩耗進展よりもマイルドな状況で進展するものと考 えられる，つまり，混合すべりは式(6)に示すように，接触面内における縦すべりと横すべりの寄与率によって， その進展を評価することができる可能性が考えられる. そこで, Case1 ならびに Case2 における摩耗係数につい て，縦すべりならびに横すべりの寄与率で評価できるか検討した．なお式(6)において， $k_{m}$ は混合すべり条件にお ける摩耗係数の推定值， $k_{x}$ は縦すべり条件における摩耗係数， $k_{y}$ は横すべり条件における摩耗係数， $\delta_{x}$ は混合す ベり条件における縦すべり率， $\delta_{y}$ は混合すべり条件における横すべり率である.

$$
k_{m}=\frac{\delta_{x}}{\delta_{x}+\delta_{y}} k_{x}+\frac{\delta_{y}}{\delta_{x}+\delta_{y}} k_{y}
$$

Case1 ならびに Case2 における摩耗係数について，室内摩耗試験結果から同定した摩耗係数，ならびに式(6)で 示す縦すべりと横すべりの寄与率による推定式から摩耗係数を算出した. それらの結果を図 8 に示す.

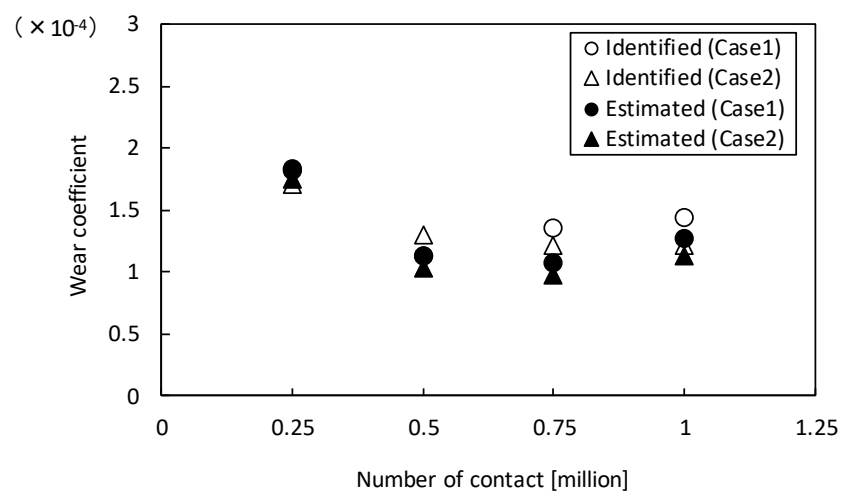

Fig. 8 The results of the wear coefficient of rail discs at every 0.25 million rotations under the mixed slip conditions. The results of wear coefficient indicated by open circles and open triangles were identified the results of wear experiment in this study. On the other hand, the results indicated by solid circles and solid triangles were estimated by equation (6).

図 8 に示すように，Case1 ならびに Case2 ともに，実験結果から同定した摩耗係数ならびに寄与率により推定 した摩耗係数は，若干のばらつきはあるものの，概ね一致していることが確認できた．またその誤差は，最大で も 2 割程度に収まっている結果となった。 これらの結果より，本研究で行ったすべり条件以外の混合すべりによ る摩耗進展に対しても, 縦すべりのみ／横すべりのみの室内摩耗試験から同定した摩耗係数により，その混合す ベりにおける摩耗係数を推定できることが見込まれる.

\section{5. 摩耗進展解析}

本章では，前章で提案した混合すべりにおける摩耗係数の推定式が，摩耗進展予測に及ぼす影響を評価するた めに，3 章で実施した室内摩耗試験と同じ条件で摩耗進展解析を行った。 そして，前章で提案した摩耗係数の推 定式が摩耗進展予測に及ぼす影響について評価した。

\section{$5 \cdot 1$ 解析モデル}

本節では, 筆者らが先行研究(辻江他，2017)において構築した，レール摩耗形状予測モデルの概要について記 述する. 
(1) 摩耗形状予測モデル

マルチボディダイナミクスツールであるSimpackを援用した,レール摩耗形状予測モデルの概略を図9に示す.

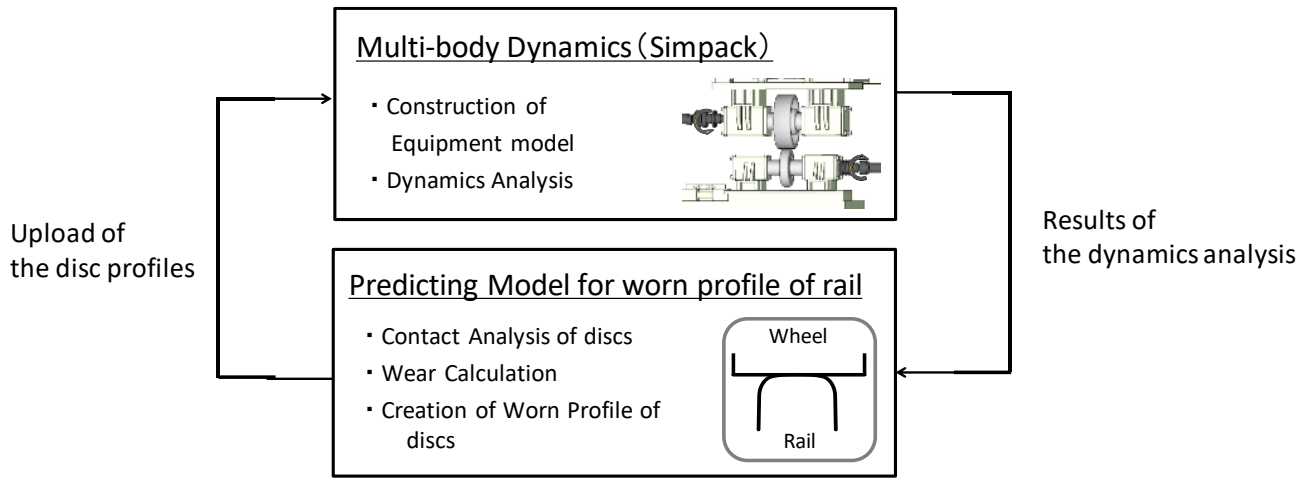

Fig. 9 Prediction procedures of wear development.

図 9 に示寸ように，本モデルはマルチボディダイナミクスツールである Simpack，ならびに独自に構築した摩 耗形状予測モデルから構成されている．解析手順は以下のとおりである.

はじめに，Simpack 上で対象となる試験装置モデルを構築し，試験輪の運動解析を行う。そして Simpackによ る解析から得られる車輪/レール輪の接触点位置や接触荷重，すべり率といった解析結果をもとに，車輪／レー 儿輪の接触解析を行い，各試験輪における摩耗量を算出する. Simpack 上に配置した試験輪の断面形状から各試 験輪における摩耗量を差し引くことで，摩耗断面形状を形成する．そして，それらの断面形状を Simpack 上の試 験輪モデルに再配置する，その後，摩耗断面形状の試験輪が組み込まれた試験装置モデルにて，再び試験輪の運 動解析を実施する.

上記に示す一連の手順を繰り返すことで, 試験輪の接触による摩耗進展に応じた, 試験輪の断面形状変化を予 測することができる，なお試験輪における摩耗進展については，前章で記述した Archard の摩耗則を適用し，摩 耗量を算出した.

（2）試験装置のモデル化

本研究における摩耗進展解析については，図9 に示寸レール摩耗形状予測モデルの Simpack で行うモデル構築 ならびに運動解析について, 図 2 に示す室内摩耗試験装置をモデルとした. 試験装置モデルの概略図を図 10 に示 す.

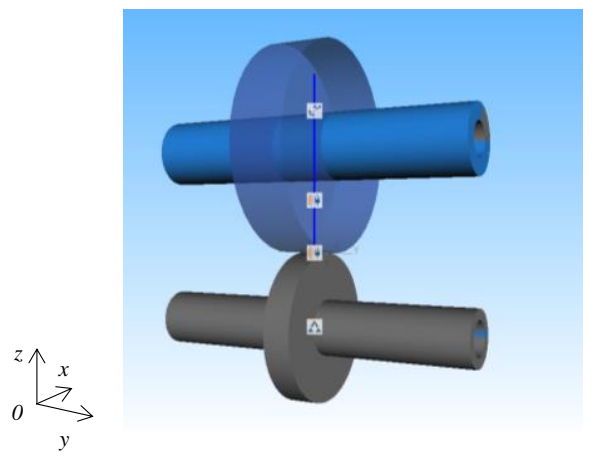

Fig. 10 The outline of Simpack model. 
本モデルでは，車輪ならびにレール輪は完全に剛体で，上下方向（z 軸）以外は拘束されているものとし，車 輪とレール輪は弾性接触するものとしている。したがって，各試験輪の接触によって作用する荷重とす心゙りのみ が試験輪の摩耗に影響するものと考えることができる.

また本モデルにおける試験輪の断面形状は, 図 11 に示すように車輪が 301 点, レール輪が 351 点の座標デー タを $0.4 \mathrm{~mm}$ 間隔で配置することで構成した。これらの座標点を用いて，車輪／レール接触部における摩耗深さを 算出するとともに，摩耗断面形状が構成される。また摩耗断面形状の更新については，試験輪が 2.5 万回転動す るごとに新しい摩耗断面形状を形成し, 解析モデルに反映させた. なお断面形状の更新は, レール輪だけでなく, 車輪についても同様に行った.

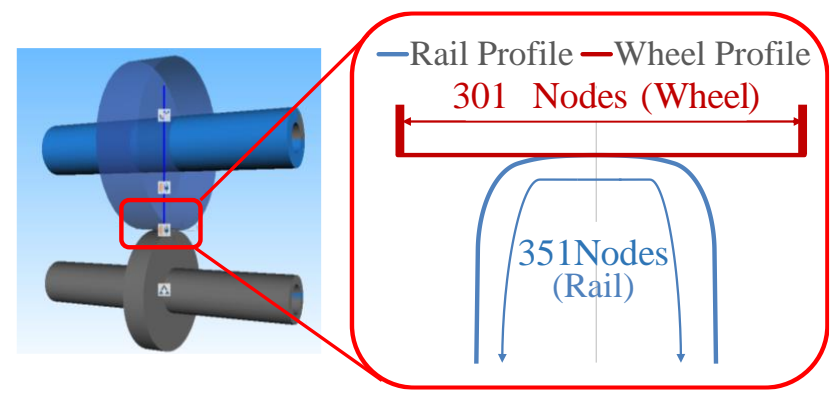

Fig. 11 The data point of wheel/rail disc profiles. The profile of wheel disc is composed of 301 nodes and the profile of rail disc is composed of 351 nodes.

\section{2 解析条件}

摩耗進展解析における転動条件（転動速度，アタック角，ラジアル荷重）は，表 3 に示すように， 3 章で行っ た室内摩耗試験と同じ条件で行った。また, 試験輪接触面におけるすべり率についても, 室内摩耗試験と同様, Case1 がアタック角 $0.2^{\circ}$ （縦す心゙り：0.35\%, 横すべり : 0.35\%), Case 2 がアタック角 $0.1^{\circ} \quad$ (縦すべり : $0.35 \%$, 横すべり：0.17\%）と設定した.

Table 3 Analytical conditions.

\begin{tabular}{c|c|c}
\hline & Case1 & Case2 \\
\hline Diameter of wheel $[\mathrm{mm}]$ & \multicolumn{2}{|c}{500} \\
\hline Diameter of rail $[\mathrm{mm}]$ & \multicolumn{2}{|c}{350} \\
\hline Wheel profile & \multicolumn{2}{|c}{ Cylinder $(\mathrm{R}=\infty)$} \\
\hline Rail profile & JIS 60 kg Rail $(\mathrm{R}=600 \mathrm{~mm})$ \\
\hline Rotation speed of wheel disc $[\mathrm{km} / \mathrm{h}]$ & \multicolumn{2}{|c}{60.21} \\
\hline Rotation speed of rail disc $[\mathrm{km} / \mathrm{h}]$ & \multicolumn{2}{|c}{60.00} \\
\hline Radial stress $[\mathrm{kN}]$ & 0.2 & 0.1 \\
\hline Angle of attack $[\mathrm{deg}]$ & 0.35 & 0.35 \\
\hline Longitudinal slip ratio $[\%]$ & 0.35 & 0.17 \\
\hline Lateral slip ratio $[\%]$ &
\end{tabular}

さらに, 前章で記述した摩耗係数の推定式が摩耗進展予測へ及ぼす影響について評価するために, 摩耗進展解 析に用いる摩耗係数については，(i)室内摩耗試験結果から同定した值，(ii)摩耗係数推定式（式(6)）により推定し た值，を採用した。 そして Case1 ならびに Case2 ともに，上記の 2 条件で解析を行った. 


\section{$5 \cdot 3$ 解析結果}

前節で示す条件で行った摩耗進展解析結果について, 25 万回転動ごとの摩耗深さの分布を, 解析条件別に図 12 に示す.なお各図とも, 用いた摩耗係数の值（(i)室内摩耗試験結果から同定，(ii)摩耗係数推定式より推定）によ る解析結果を重ねてプロットした.

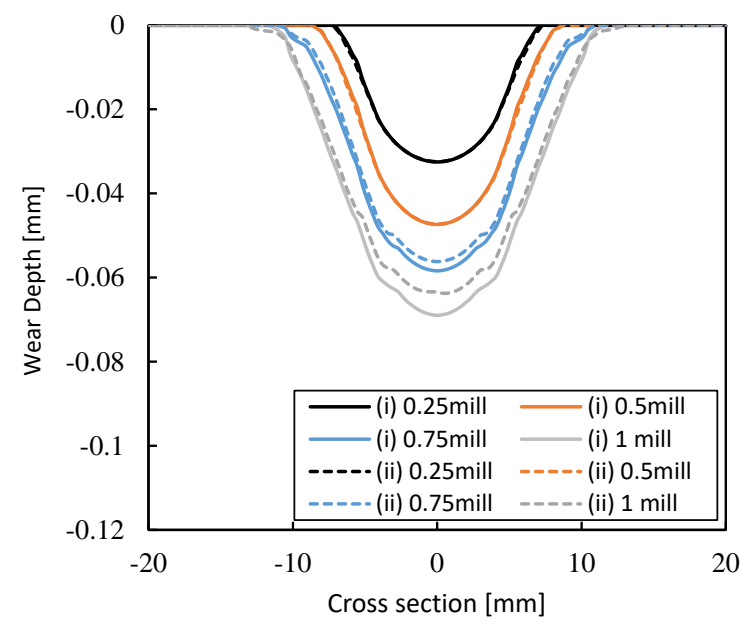

(a) Case1

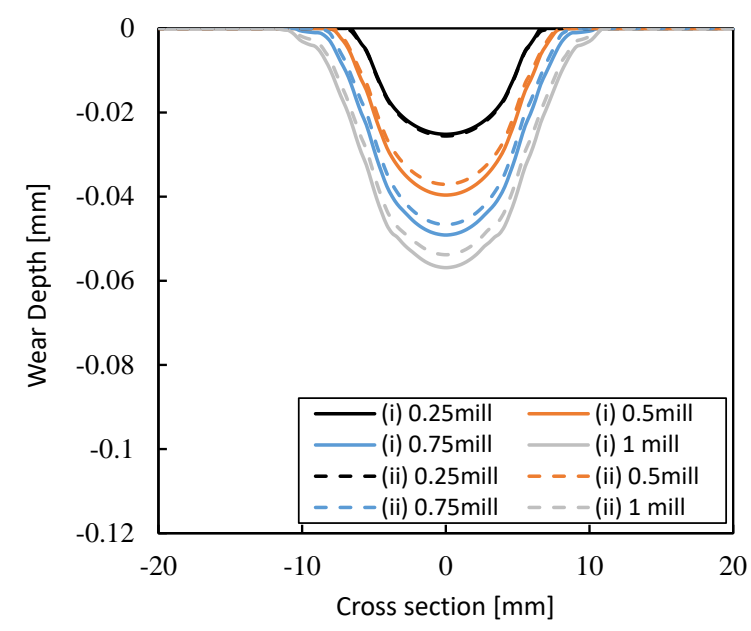

(b) Case 2

Fig. 12 The analytical results of wear development of rail disc. (a) Wear amount distribution of rail disc for Case 1 at every 0.25 million rotation. (b) Wear amount distribution of rail disc for Case 2 at every 0.25 million rotation. These prediction analysis were calculated by using (i) the wear coefficient based on the results of wear experiment (ii) the wear coefficient based on the estimation which proposed in this study.

図 12 に示すように, いずれの条件においても転動回数が増加するにつれて, 摩耗深さならびに摩耗帯域が増加 していることが確認できる．またCase1 においては，50 万回転動までの解析結果について，いずれの摩耗係数の 值による結果とも，ほぼ一致していることを確認した。また Case2 においても，25 万回転動の結果については， 両者ともほぼ一致する結果であった。転動回数が増加するにつれて, 用いた摩耗係数の值による解析結果は, 摩 耗帯域や摩耗深さにおいてわずかに誤差が認められたものの，いずれも10\%以下に収まっていた.

先行研究(辻江他，2017)では，室内摩耗試験結果ならびに室内摩耗試験と同じ条件で実施した摩耗進展解析結 果を比較したところ, 両者において 2～3 割程度の誤差が認められた. このような誤差が生じた要因として, 室内 摩耗試験において実施した摩耗量測定での測定誤差や試験中に試験輪接触部に生じた動的変動，また試験輪の初 期形状における製造誤差などが影響したと考えられる。このように現段階では，摩耗進展という動的現象につい ての再現性や定量的な評価は難しいが，接触面形状のなじ夕による摩耗帯域の増加や摩耗進展量の低下(菊池他, 1998)など，定性的には摩耗進展を予測できていると考えられる．一方，本研究において提案した，混合すべりに おける摩耗係数の推定による摩耗進展解析での誤差は $10 \%$ 以下に収まっている.したがって, 縦/横す心゙りの寄 与率により推定した摩耗係数を用いた解析結果は，室内摩耗試験結果から同定した摩耗係数による解析結果とお おむね一致していると考えられる。

これらの結果より，本研究で提案した，縦／横すべりの寄与率により車輪／レール接触部における混合すべり による摩耗進展について，精度よくその進展を予測できると考えられる。また，本研究で実施した条件以外の混 合すべりによる摩耗進展についても，縦／横すべりの寄与率により評価できると考えられる.

\section{6. 結 言}

本研究では，縦すべりと横すべりが同時に作用した，混合すべりによるレール摩耗形状予測モデルを構築する ために, 大型転動疲労試験機を用いた室内摩耗試験ならびにマルチボディダイナミクスによる摩耗進展解析を実 
施した，そして，混合すべりがレールの摩耗進展に及ぼす影響について検討するとともに，混合すべりによる摩 耗進展を予測する摩耗係数推定式を提案した. 得られた結果を以下に示す.

・室内摩耗試験より，混合すべり条件下における縦すべりと横すべりの割合に応じて，摩耗進展状況が異なる ことを明らかにした．また，これらの摩耗進展の差は，同定した摩耗係数の值に反映していることが確認で きた。

・混合すべり条件下における摩耗進展について，接触部における縦すべりと横すべりの寄与率により摩耗係数 を推定する手法を提案した，そして，室内摩耗試験の結果より同定した摩耗係数の值と，提案手法により推 定した摩耗係数の值は，おおむむ致することを確認した.

・室内摩耗試験と同じ条件で実施した摩耗進展解析において, 提案手法から推定した摩耗係数ならびに室内摩 耗試験結果から同定した摩耗係数による解析結果については，両者の誤差は 10\%以下に収まっていた。した がって, 混合すべり条件下における摩耗進展予測については, 本研究で提案した縦／横すべりの寄与率によ り，精度よく予測できることを示した。

\section{文献}

Archard, J. F., Contact and rubbing of flat surface, Journal of Applied Physics, Vol.24 (1953), pp.981-988.

Arizon, J., Verlinden, O. and Dehombreux, P., Prediction of wheel wear in urban railway transport: comparison of existing, Vehicle System Dynamics, Vol.45, No.9 (2007), pp.849-874.

Bevan, A., Molyneux-Berry, P. and Eickhoff, B., Development and validation of a wheel wear and rolling contact fatigue damage model, Wear, Vol.307 (2013), pp.100-111.

土井久代, 下村隆行, 金鷹, 宮本岳史, 名村明, 実断面形状の室内摩耗試験に基づく車輪・レールの摩耗進展シミ ユレーション，日本機械学会第 20 回交通・物流部門大会講演論文集 (2011), pp. 211-214.

Elkins, J. A. and Eickhoff, B. M., Advances in nonlinear wheel/rail force prediction methods and their validation, Proceedings of the ASME winter annual meeting (1979).

Ignesti, M., Malvezzi, M., Marini, L., Meli, E. and Rindi, A., Development of a wear model for the prediction of wheel and rail profile evolution in railway systems, Wear, Vol.284-285 (2012), pp.1-17.

金鷹，石田誠，青木宜頼，レールきしみ割れ発生原因についての調査と解析，鉄道総研報告，Vol.20, No.11 (2006), pp. 29-34.

金鷹，名村明，石田誠，レール頭部の摩耗形状予測手法，鉄道総研報告, Vol.23, No.2 (2009), pp. 5-10.

Kalousek, J. and Bethune, A. E., Rail wear under heavy traffic conditions, STP, Vol.644 (1978), pp.63-79.

菊池賢靖, 神谷修, 齋藤省律, 熊谷一男, 繰り返し摩耗におけるなじみ機構について, 素材物性学杂倠誌, Vol.11, No.2 (1998), pp. 12-20.

栗原利喜雄，レール損傷に関寸る研究，鉄道技術研究報告, No.1188 (1981), pp. 5-10.

名村明, 石田誠, レール損傷の発生メカニズムを探る, RRR, Vol.68, No.9 (2011), pp. 6-9.

Rene, H. and Marcel, B., Empirical studies of head check propagation on the DB network, Wear, Vol.314 (2014), pp.36-43.

下川嘉之, 亀甲智, 齋藤拓也, 岩本厚, 荻野智久, 鈴木芳明, 谷藤克也, 車輪の摩耗予測に関する研究（第 1 報, 試 験片を用いた摩耗試験結果），第 17 回鉄道技術連合シンポジウム（J-Rail2010）予稿集 (2010), pp. 645-648.

瀧川光伸, 石田誠, 曾根康友, 車輪 /レールの動的挙動に与える摩耗と潤滑の影響, 鉄道総研報告, Vol.16, No.4 (2002), pp. 35-40.

Telliskivi, T., Simulation of wear in a rolling-sliding contact by a semi-Winkler model and the Archard's wear law, Wear, Vol.256 (2004), pp.817-831.

日本トライボロジー学会編, 摩擦・摩耗試験機とその活用 (2007), pp. 223-224, 養賢堂.

辻江正裕, 松本春花, 曄道佳明, 横すべりを考慮したレール摩耗形状予測モデルの構築, 日本機械学会論文集, Vol.84, No.866 (2018), DOI: 10. 1299/transjsme.18-00104.

辻江正裕, 三苫雅史, 曄道佳明, MBD ソフトを援用した摩耗形状予測とその考察, 日本機械学会論文集 C 編, Vol.79, No.806 (2013), pp. 3376-3388.

辻江正裕, 吉岡亜陸, 水谷祐貴, 曄道佳明, マルチボディダイナミクスによるレール摩耗形状予測モデルの構築と 妥当性の検証, 日本機械学会論文集, Vol.83, No.854 (2017), DOI: 10. 1299/transjsme.17-00074. 
Ward, A., Lewis, R. and Dwyer-Joyce, R. S., Incorporating a railway wheel wear model into multibody simulations of wheelset dynamics, Tribology Series, Vol.41 (2003), pp.367-376.

Zhou, Y., Wang, S., Wang, T., Xu, Y. and Li, Z., Field and laboratory investigation of the relationship between rail head check and wear in a heavy-haul railway, Wear, Vol.315 (2014), pp.68-77.

\section{References}

Archard, J. F., Contact and rubbing of flat surface, Journal of Applied Physics, Vol.24 (1953), pp.981-988.

Arizon, J., Verlinden, O. and Dehombreux, P., Prediction of wheel wear in urban railway transport: comparison of existing, Vehicle System Dynamics, Vol.45, No.9 (2007), pp.849-874.

Bevan, A., Molyneux-Berry, P. and Eickhoff, B., Development and validation of a wheel wear and rolling contact fatigue damage model, Wear, Vol.307 (2013), pp.100-111.

Doi, H., Shimomura, T., Jin, Y., Miyamoto, T. and Namura, A., Wheel/rail wear simulation based on a laboratory experiment with full-scale wheel/rail transversal profiles, Translog2011 (2011), pp.211-214 (in Japanese).

Elkins, J. A. and Eickhoff, B. M., Advances in nonlinear wheel/rail force prediction methods and their validation, Proceedings of the ASME winter annual meeting (1979).

Ignesti, M., Malvezzi, M., Marini, L., Meli, E. and Rindi, A., Development of a wear model for the prediction of wheel and rail profile evolution in railway systems, Wear, Vol.284-285 (2012), pp.1-17.

Jin, Y., Ishida, M. and Aoki, F., Investigation and analysis on the initiation of rail head checks, RTRI Report, Vol.20, No.11 (2006), pp.29-34 (in Japanese).

Jin, Y., Namura, A. and Ishida, M., A predictive method of wear profile of rail head, RTRI Report, Vol.23, No.2 (2009), pp.5-10 (in Japanese).

Kalousek, J. and Bethune, A. E., Rail wear under heavy traffic conditions, STP, Vol.644 (1978), pp.63-79.

Kikuchi, K., Kamiya, O., Saito, Y. and Kumagai, K., Running-in behavior of repeated dry wear on metals, Journal of the society of materials engineering for resources of Japan, Vol.11, No.2 (1998), pp. 12-20 (in Japanese).

Kurihara, T., Study on rail failures, Railway Technical Research Report, No.1188 (1981), pp.5-10 (in Japanese).

Namura, A. and Ishida, M., A study of the mechanism for rail defects, Railway Research Report, Vol.68, No.9 (2011), pp.6-9 (in Japanese).

Rene, H. and Marcel, B., Empirical studies of head check propagation on the DB network, Wear, Vol.314 (2014), pp.36-43.

Shimokawa, Y., Kikko, S., Saito, T., Iwamoto, A., Ogino, T., Suzuki, Y. and Tanifuji, K., A study on wear prediction of railway wheel ( $1^{\text {st }}$ report, Bench test), J-Rail 2010 (2010), pp.645-648(in Japanese).

Takikawa, M., Ishida, M. and Sone, Y., Influence of rail gauge face wear and lubrication on wheel/rail dynamics behavior, RTRI Report, Vol.16, No.4 (2002), pp.35-40 (in Japanese).

Telliskivi, T., Simulation of wear in a rolling-sliding contact by a semi-Winkler model and the Archard's wear law, Wear, Vol.256 (2004), pp.817-831.

The Japanese Society of Tribologists ed., Applications for the equipment of friction and wear (2007), pp.223-224, Yokendo (in Japanese).

Tsujie, M., Matsumoto, H. and Terumichi, Y., Development of a model for predicting worn profile of rail considering lateral slip, Transactions of the JSME (in Japanese), Vol.84, No.866 (2018), DOI: 10.1299/transjsme.18-00104.

Tsujie, M., Mitoma, M. and Terumichi, Y., A study on the developing of a model for predicting worn profile of rail by use of multi-body dynamics software, Transactions of the Japan Society of Mechanical Engineers, Series C, Vol.79, No.806 (2013), pp.3376-3388(in Japanese).

Tsujie, M., Yoshioka, A., Mizutani, Y. and Terumichi, Y., A study on the modelling for predicting worn profile of rail with multi-body dynamics and the verifying the validity, Transactions of the JSME (in Japanese), Vol.83, No.854 (2017), DOI: 10.1299/transjsme.17-00074.

Ward, A., Lewis, R. and Dwyer-Joyce, R. S., Incorporating a railway wheel wear model into multibody simulations of wheelset dynamics, Tribology Series, Vol.41 (2003), pp.367-376.

Zhou, Y., Wang, S., Wang, T., Xu, Y. and Li, Z., Field and laboratory investigation of the relationship between rail head check and wear in a heavy-haul railway, Wear, Vol.315 (2014), pp.68-77. 